\title{
ASUPAN IODIUM ANAK USIA SEKOLAH DI INDONESIA
}

\author{
Djoko Kartono ${ }^{1}$ dan Donny K. Mulyantoro² \\ ${ }^{1}$ Pusat Penelitian dan Pengembangan Gizi dan Makanan, Bogor \\ ${ }^{2}$ Balai Penelitian dan Pengembangan GAKI, Magelang
}

\begin{abstract}
\end{abstract}
\section{IODINE INTAKE AMONG SCHOOL-AGED CHILDREN IN INDONESIA}

lodine Deficiency Disorders (IDD) has been recognized in many areas mainly around volcanoes in Indonesia for a long time. Fortification of salt with iodine has been used for national IDD control for over two decades. Monitoring survey of iodized salt was conducted regularly by Central Bureau of Statistics and Ministry of Health. In 2007, national survey on iodine was conducted by Ministry of Health through Basic Health Research. The objective of this article is to study the intake of iodine through iodized salt at household level and urinary iodine concentration (UIC) among school-aged children (6-12 years). Rapid test for iodine content in households salt was carried out throughout the country (280.000 households). Meanwhile, the UIC of 8.250 children's casual urin sample were carried out from 30 selected districts/cities. Selection of 30 districts/cities was using stratified random sampling from all districts/cities throughout the country. Overall, from the rapid test survey showed that $62,3 \%$ households salt contained sufficient iodine. Only $14 \%$ of households salt contained no iodine. The median value of UIC among school-aged children was $224 \mu \mathrm{g} / \mathrm{L}$ or far higher than the define population of iodine deficiency. The distribution of UIC values were as follows: $12,9 \%$ of children had UIC value less than $100 \mu \mathrm{g} / \mathrm{L}, 65,2 \%$ between $100-299 \mu \mathrm{g} / \mathrm{L}$, and $21,9 \%$ had UIC value $300 \mu \mathrm{g} / \mathrm{L}$ or over. UIC value of $300 \mu \mathrm{g} / \mathrm{L}$ or over is regarded as having the risk of iodine excess. Children with UIC value $300 \mu \mathrm{g} / \mathrm{L}$ or over were found in almost all of the districts/cities. The majority of household salt contained iodine but has not reached the universal salt iodisation. Median value of UIC of school age children that is the proxy of iodine intake is under the tolerable upper intake level.

Keywords: school aged children, household, iodized salt, urinary iodine

\section{PENDAHULUAN}

S alah satu upaya pemerintah Indonesia untuk meningkatkan kualitas sumber daya manusianya adalah dengan cara eliminasi penduduknya dari kekurangan iodium. lodium merupakan zat gizi mikro penting untuk pertumbuhan fisik dan perkembangan mental. Konsekuensi dari kekurangan iodium, yaitu Gangguan Akibat Kekurangan lodium (GAKI), mencakup gondok pada semua umur, kretin endemik yang ditandai dengan keterbelakangan mental, bisu-tuli, meningkatnya angka lahir mati, kematian perinatal dan bayi ${ }^{1}$. Rata-rata IQ poin anak yang kekurangan iodium adalah 13,5 lebih rendah dibandingkan dengan anak yang cukup iodium².

Kekurangan iodium umumnya lebih disebabkan karena faktor lingkungan daripada faktor sosial ekonomi. Koreksi terhadap kekurangan iodium dapat dicapai dengan memberikan tambahan iodium. Di Indonesia, kalium iodat $\left(\mathrm{KIO}_{3}\right)$ digunakan untuk iodisasi garam dengan kandungan minimal 30 bagian per juta (part per million, ppm). Kriteria ICCIDD/ UNICEF/ WHO untuk eliminasi GAKI dari suatu negara adalah jika minimal 90 persen rumah tangga mengonsumsi (menggunakan) garam mengandung cukup iodium. Pencapaian ini disebut sebagai telah tercapainya Garam Beriodium untuk Semua atau Universal Salt Iodization (USI). Pada tahun 1990-an hanya sekitar 20 persen rumah tangga di negara sedang berkembang menggunakan garam beriodium dan menjelang dekade pertama tahun 2000-an telah mencapai sekitar 70 persen ${ }^{3}$. Data penggunaan garam iodium yang mengandung cukup iodium oleh rumah tangga di Indonesia menunjukkan 50 persen pada tahun 1995 dan 64 persen pada tahun $2000^{4}$.

Penggunaan ekskresi iodium dalam urin sebagai biomarker iodium dapat memberikan gambaran yang baik tentang asupan iodium terkini5. Itu disebabkan semua iodium yang diserap tubuh pada akhirnya dikeluarkan melalui urin. Kecenderungan variasi individu pada ekskresi iodium dalam urin dapat diatasi jika penilaian dilakukan di suatu masyarakat 
dalam jumlah yang memadai. Penelitian menunjukkan bahwa ekskresi iodium dalam urin sesaat memberikan gambaran yang baik tentang asupan iodium suatu masyarakat.

Pemantauan program garam beriodium telah dilakukan secara berkala terintegrasi dalam Survei Sosial Ekonomi Nasional (SUSENAS) oleh Badan Pusat Statistik (BPS) dan Departemen Kesehatan sejak 1995. Tahun 2007, survei nasional garam beriodium dilakukan oleh Departemen Kesehatan dalam Riset Kesehatan Dasar (Riskesdas) juga mengumpulkan sampel garam rumah tangga dan sampel urin sesaat anak usia sekolah.

Sasaran dan indikator pencapaian program penanggulangan GAKI pada 2010 secara nasional, provinsi dan kabupaten/kota adalah persentase rumah tangga yang mengonsumsi garam mengandung cukup iodium adalah lebih 90 persen dan nilai median EIU 100-299 $\mu \mathrm{g} / \mathrm{L}^{6}$. Survei indikator GAKI ini bertujuan untuk mempelajari konsumsi garam beriodium rumah tangga secara kualitatif dan kuantitatif, serta mempelajari kandungan iodium dalam urin anak usia sekolah (6-12 tahun).

\section{METODE PENELITIAN}

Survei dilaksanakan di semua provinsi (33 provinsi) dan semua kabupaten/kota menggunakan sampel SUSENAS. Jumlah rumah tangga yang di survei sama dengan jumlah sampel rumah tangga SUSENAS yaitu 280.000. Cara pemilihan sampel rumah tangga adalah sebagai berikut: i) pemilihan blok sensus menggunakan 'probability proportional to size (PPS) linear systematic sampling' dimana besar sampel adalah jumlah rumah tangga dari daftar registrasi di setiap blok sensus. Sebanyak 16 rumah tangga dipilih dari setiap blok sensus terpilih.

Dari rumah tangga ini akan diperoleh nilai perkiraan untuk tingkat kabupaten/kota, provinsi dan nasional. Data yang dikumpulkan mencakup kandungan iodium menggunakan tes cepat terhadap garam yang dikonsumsi oleh 280.000 rumah tangga dari semua kabupaten/kota, dan sampel urin sesaat untuk menilai ekskresi iodium dalam urin di 30 kabupaten/kota terpilih.

Pemilihan 30 kabupaten/kota didasarkan pada hasil Survei Garam Beriodium tahun $2005^{7}$ (417 kabupaten/kota) menggunakan "stratified random sampling" sebagai berikut: i) kabupaten/kota diurutkan (dari yang terendah ke yang tertinggi) berdasarkan persentase rumah tangga yang mengonsumsi garam mengandung cukup iodium (>=30 ppm), ii) kabupaten/kota dikelompokkan menjadi tiga (3), iii) kelompok 1: kabupaten/kota di mana kurang 50 persen $(<50 \%)$ rumah tangga mengonsumsi garam mengandung cukup iodium (58 kabupaten/kota), iv) kelompok 2: kabupaten/kota di mana angtara 50-80 persen rumah tangga mengonsumsi garam mengandung cukup iodium (136 kabupaten/kota), v) kelompok 3: kabupaten/kota di mana lebih 80 persen rumah tangga mengonsumsi garam mengandung cukup iodium (223 kabupaten/kota), vi) secara proporsional: sebanyak 4 kabupaten/kota dipilih dari kelompok 1, sebanyak 10 kabupaten/kota dari kelompok 2 dan 16 kabupaten/kota dari kelompok 3, vii) 30 kabupaten/kota itu dipilih secara acak.

\section{Kadar iodium garam dalam rumah tangga menggunakan metode tes cepat}

Tes ini dilakukan langsung di lapangan (di tiap rumah tangga) dan di semua blok sensus di semua kabupaten/kota. Alat tes cepat adalah larutan dalam botol plastik $(10 \mathrm{ml})$. Dua tetes larutan cukup untuk penentuan setiap sampel garam dari rumah tangga. Satu botol dapat digunakan untuk sekitar 50 kali tes. Cara melakukan tes cepat adalah: i) sampel garam dari sekitar 280.000 rumah tangga, ii) ambil 1 sendok teh sampel garam yang dikonsumsi oleh rumah tangga, iii) letakan garam di piring kecil, iv) tetesi (2 tetes) garam dengan larutan tes cepat, v) perhatikan, segera, perubahan warna pada garam, vi) warna ungu/biru tua berarti mengandung cukup iodium (> $30 \mathrm{ppm}$ ), abuabu/biru muda berarti mengandung kurang iodium (<30 ppm) dan tidak ada perubahan warna berarti tidak mengandung iodium (0 ppm).

\section{Kadar iodium urin dengan sampel urin sesaat}

Cara mengumpulkan sampel urin sesaat adalah: i) anak diminta untuk kencing yang ditampung pada wadah plastik sementara, ii) minimal $10 \mathrm{cc}$ sampel urin dituangkan dari wadah plastik sementara ke dalam botol plastik yang telah disiapkan, iii) botol plastik ditutup 
rapat baik yang dalam maupun yang luar. Tutup botol diberi selotip agar tidak terjadi bocor, iv) botol diberi label yang telah disediakan. Duplikat label juga ditempelkan di kuesioner dan pada formulir yang memuat daftar anak, v) kirimkan sampel urin ke laboratorium GAKI sesuai daftar.

\section{HASIL}

\section{Kadar iodium dalam garam rumah tangga}

Secara keseluruhan, Indonesia (perkotaan dan perdesaan), sebanyak 62,3 persen rumah tangga (Tabel 1) mengonsumsi garam mengandung cukup iodium atau masih belum mencapai target garam beriodium untuk semua. Sebanyak 23,7 persen rumah tangga mengonsumsi garam mengandung kurang iodium dan 14,0 persen tidak mengandung iodium. Persentase rumah tangga yang mengonsumsi garam tidak mengandung iodium, tertinggi di Nusa Tenggara Timur (47,8\%) disusul Bali $(42,9 \%)$ dan NTB $(42,5 \%)$.

Tabel 1

Persentase Rumah Tangga Menurut Provinsi dan Kandungan lodium Dalam Garam (Perkotaan dan Perdesaan)

\begin{tabular}{|c|c|c|c|}
\hline \multirow{2}{*}{ Provinsi } & \multicolumn{3}{|c|}{ Kandungan lodium Rumah Tangga (\%) } \\
\hline & Cukup & Kurang & Tidak ada \\
\hline Nanggroe Aceh Darussalam & 47.3 & 24.7 & 28.0 \\
\hline Sumatera Utara & 89.9 & 9.8 & 0.3 \\
\hline Sumatera Barat & 90.3 & 9.3 & 0.4 \\
\hline Riau & 82.8 & 15.7 & 1.5 \\
\hline Jambi & 94.0 & 5.6 & 0.4 \\
\hline Sumatera Selatan & 93.0 & 6.7 & 0.3 \\
\hline Bengkulu & 69.7 & 28.5 & 1.8 \\
\hline Lampung & 76.8 & 18.1 & 5.1 \\
\hline Kepulauan Bangka Belitung & 98.7 & 1.1 & 0.2 \\
\hline Kepulauan Riau & 89.1 & 6.7 & 4.2 \\
\hline DKI Jakarta & 68.7 & 21.5 & 9.8 \\
\hline Jawa Barat & 58.3 & 27.1 & 14.6 \\
\hline Jawa Tengah & 58.6 & 26.1 & 15.3 \\
\hline DI Yogyakarta & 82.7 & 14.1 & 3.2 \\
\hline Jawa Timur & 45.1 & 34.3 & 20.6 \\
\hline Banten & 46.4 & 34.5 & 19.1 \\
\hline Bali & 37.5 & 19.6 & 42.9 \\
\hline Nusa Tenggara Barat & 27.9 & 29.7 & 42.4 \\
\hline Nusa Tenggara Timur & 31.0 & 21.2 & 47.8 \\
\hline Kalimantan Barat & 84.4 & 14.8 & 0.8 \\
\hline Kalimantan Tengah & 88.7 & 9.8 & 1.5 \\
\hline Kalimantan Selatan & 76.2 & 18.1 & 5.7 \\
\hline Kalimantan Timur & 83.8 & 13.0 & 3.2 \\
\hline Sulawesi Utara & 89.2 & 10.1 & 0.7 \\
\hline Sulawesi Tengah & 62.3 & 33.6 & 4.1 \\
\hline Sulawesi Selatan & 61.0 & 15.8 & 23.2 \\
\hline Sulawesi Tenggara & 43.5 & 42.6 & 13.9 \\
\hline Gorontalo & 90.1 & 9.5 & 0.4 \\
\hline Sulawesi Barat & 34.2 & 58.8 & 7.0 \\
\hline Maluku & 45.1 & 26.0 & 28.9 \\
\hline Maluku Utara & 83.0 & 7.6 & 9.4 \\
\hline Papua & 90.9 & 8.8 & 0.3 \\
\hline Irian Jaya Barat & 86.2 & 12.9 & 0.9 \\
\hline Indonesia & 62.3 & 23.7 & 14.0 \\
\hline
\end{tabular}

Di perkotaan, menunjukkan 70,4 persen rumah tangga mengonsumsi garam mengandung cukup iodium (baca: iodat), 20,8 persen mengandung kurang iodium $(<30 \mathrm{ppm})$ 
dan 8,8 persen tidak mengandung iodium (Tabel 2). Persentase rumah tangga di perkotaan yang mengonsumsi garam tidak mengandung iodium bervariasi antar provinsi, tertinggi di Nusa Tenggara Barat $(33,8 \%)$ disusul Bali (32,7\%) dan NTT (25,2\%). Di perdesaan, sebanyak 56,3 persen rumah tangga mengonsumsi garam mengandung cukup iodium, 25,8 persen mengandung kurang iodium dan 17,8 persen tidak mengandung iodium (Tabel 3). Persentase rumah tangga di perdesaan yang mengonsumsi garam tidak mengandung iodium juga bervariasi antar provinsi, tertinggi di Nusa Tenggara Timur $(54,5 \%)$ disusul Bali $(54,2 \%)$ dan NTB $(47,2 \%)$.

Tabel 2

Persentase Rumah Tangga Menurut Provinsi dan Kandungan lodium Dalam Garam (Perkotaan)

\begin{tabular}{lrrr}
\hline & \multicolumn{3}{c}{ Kandungan lodium Rumah Tangga (\%) } \\
\cline { 2 - 4 } & Cukup & Kurang & Tidak ada \\
\hline Nanggroe Aceh Darussalam & 48,4 & 26,3 & 25,3 \\
Sumatera Utara & 95,2 & 4,6 &, 2 \\
Sumatera Barat & 95,1 & 4,7 &, 2 \\
Riau & 86,2 & 12,4 & 1,4 \\
Jambi & 94,6 & 5,0 &, 4 \\
Sumatera Selatan & 98,2 & 1,6 &, 2 \\
Bengkulu & 67,1 & 30,4 & 2,5 \\
Lampung & 81,0 & 14,2 & 4,8 \\
Kepulauan Bangka Belitung & 99,0 &, 8 &, 2 \\
Kepulauan Riau & 89,0 & 6,4 & 4,6 \\
DKI Jakarta & 68,7 & 21,5 & 9,8 \\
Jawa Barat & 70,5 & 21,0 & 8,5 \\
Jawa Tengah & 67,1 & 23,6 & 9,3 \\
DI Yogyakarta & 83,5 & 15,0 & 1,5 \\
Jawa Timur & 54,3 & 34,3 & 11,4 \\
Banten & 56,1 & 29,6 & 14,3 \\
Bali & 49,1 & 18,2 & 32,7 \\
Nusa Tenggara Barat & 38,5 & 27,7 & 33,8 \\
Nusa Tenggara Timur & 65,0 & 18,9 & 16,1 \\
Kalimantan Barat & 81,7 & 17,6 &, 7 \\
Kalimantan Tengah & 89,2 & 9,0 & 1,8 \\
Kalimantan Selatan & 83,0 & 12,2 & 4,8 \\
Kalimantan Timur & 87,5 & 10,4 & 2,1 \\
Sulawesi Utara & 84,4 & 14,4 & 1,2 \\
Sulawesi Tengah & 67,5 & 29,2 & 3,3 \\
Sulawesi Selatan & 75,0 & 12,7 & 12,3 \\
Sulawesi Tenggara & 44,3 & 45,8 & 9,9 \\
Gorontalo & 92,0 & 7,5 &, 5 \\
Sulawesi Barat & 46,7 & 45,9 & 7,4 \\
Maluku & 82,1 & 8,4 & 9,5 \\
Maluku Utara & 89,3 & 5,3 & 4,9 \\
Papua & 83,7 & 16,0 &, 3 \\
Irian Jaya Barat & 90,9 & 8,5 & $, 8,8$ \\
\hline In d o n e s i a & & & \\
\hline
\end{tabular}


Ada 6 provinsi yang telah mencapai target garam beriodium untuk semua adalah Sumatera Barat $(90,3 \%)$, Jambi $(94,0 \%)$, Sumatera Selatan (93,0\%), Kepulauan Bangka Belitung $(93,0 \%)$, Gorontalo $(90,1 \%)$ dan Papua $(90,9 \%)$. Provinsi dengan persentase rumah tangga yang mengonsumsi garam mengandung cukup iodium kurang dari 40 persen adalah Bali $(37,5 \%)$, Nusa Tenggara Barat $(27,9 \%)$, Nusa Tenggara Timur $(31,0 \%)$ dan Sulawesi Barat $(34,2 \%)$. Persentase rumah tangga yang mengonsumsi garam mengandung cukup iodium menurut provinsi juga diperlihatkan pada Gambar 1.

Tabel 3

Persentase Rumah Tangga Menurut Provinsi dan Kandungan lodium Dalam Garam (Perdesaan)

\begin{tabular}{|c|c|c|c|}
\hline \multirow[t]{2}{*}{ Provinsi } & \multicolumn{3}{|c|}{ Kandungan lodium Rumah Tangga (\%) } \\
\hline & Cukup & Kurang & Tidak ada \\
\hline Nanggroe Aceh Darussalam & 47,0 & 24,3 & 28,7 \\
\hline Sumatera Utara & 85,8 & 13,9 & ,3 \\
\hline Sumatera Barat & 88,1 & 11,4 &, 5 \\
\hline Riau & 81,0 & 17,5 & 1,5 \\
\hline Jambi & 93,7 & 5,9 & , 4 \\
\hline Sumatera Selatan & 89,1 & 10,5 & , 4 \\
\hline Bengkulu & 70,6 & 27,8 & 1,6 \\
\hline Lampung & 75,7 & 19,2 & 5,1 \\
\hline Kepulauan Bangka Belitung & 98,5 & 1,2 & , 3 \\
\hline Kepulauan Riau & 89,4 & 8,1 & 2,5 \\
\hline DKI Jakarta & 46,0 & 33,3 & 20,7 \\
\hline Jawa Barat & 52,7 & 27,9 & 19,4 \\
\hline Jawa Tengah & 81,6 & 12,6 & 5,8 \\
\hline DI Yogyakarta & 39,2 & 34,4 & 26,4 \\
\hline Jawa Timur & 47,0 & 24,3 & 28,7 \\
\hline Banten & 34,3 & 40,5 & 25,2 \\
\hline Bali & 24,5 & 21,3 & 54,2 \\
\hline Nusa Tenggara Barat & 21,9 & 30,9 & 47,2 \\
\hline Nusa Tenggara Timur & 23,7 & 21,8 & 54,5 \\
\hline Kalimantan Barat & 85,3 & 13,9 & , 8 \\
\hline Kalimantan Tengah & 88,5 & 10,0 & 1,5 \\
\hline Kalimantan Selatan & 72,1 & 21,6 & 6,3 \\
\hline Kalimantan Timur & 79,3 & 16,2 & 4,5 \\
\hline Sulawesi Utara & 92,6 & 7,1 & , 3 \\
\hline Sulawesi Tengah & 61,0 & 34,7 & 4,4 \\
\hline Sulawesi Selatan & 54,5 & 17,3 & 28,2 \\
\hline Sulawesi Tenggara & 43,3 & 41,6 & 15,1 \\
\hline Gorontalo & 89,3 & 10,4 & ,3 \\
\hline Sulawesi Barat & 32,1 & 61,0 & 6,9 \\
\hline Maluku & 28,8 & 33,9 & 37,3 \\
\hline Maluku Utara & 77,9 & 9,1 & 13,0 \\
\hline Papua & 94,8 & 4,8 & ,4 \\
\hline Irian Jaya Barat & 84,4 & 14,7 & ,9 \\
\hline Indonesia & 56,3 & 25,9 & 17,8 \\
\hline
\end{tabular}




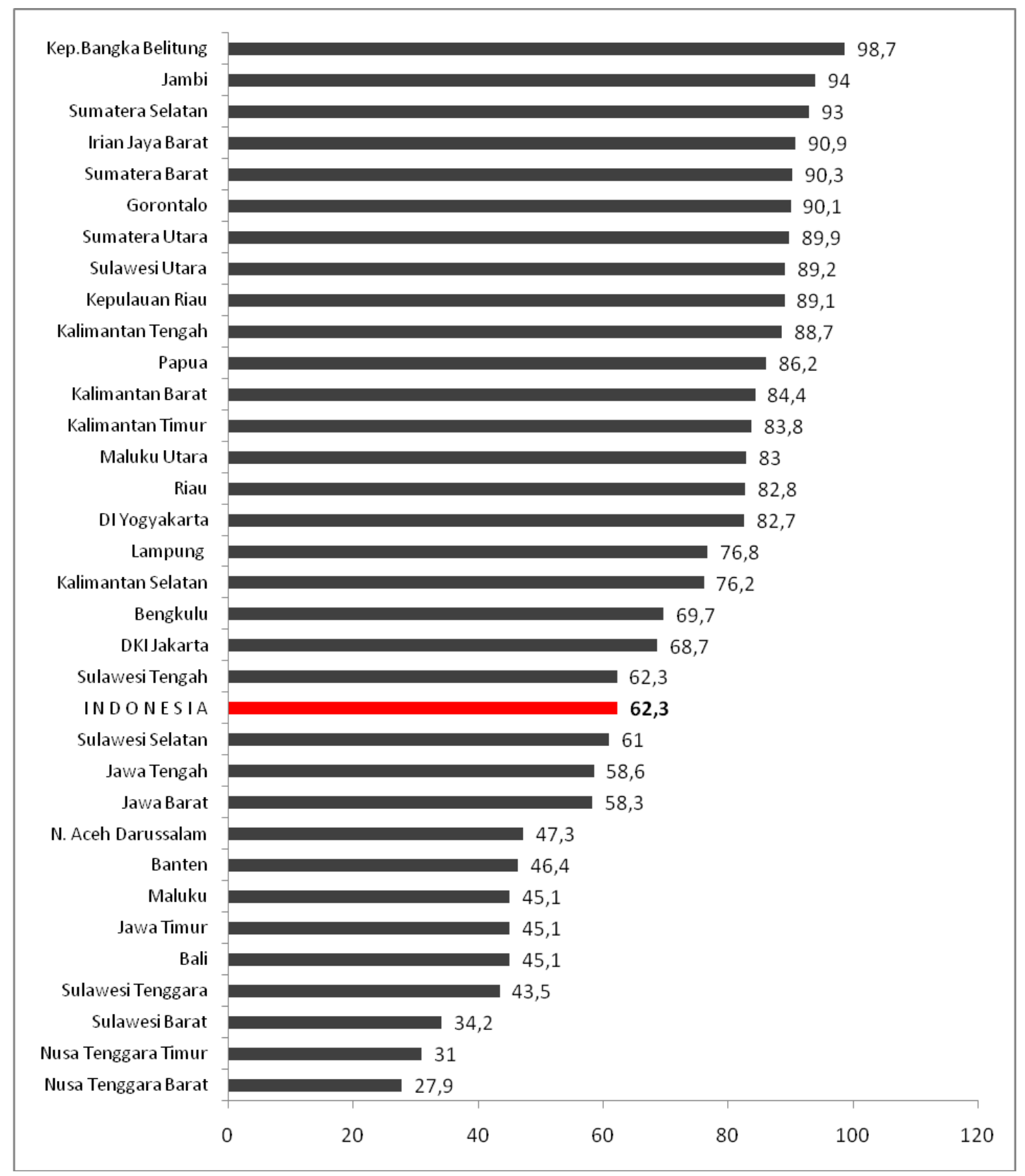

Gambar 1

Persentase Rumah Tangga Dengan Garam Mengandung Cukup lodium (>=30ppm) Hasil Tes Cepat Menurut Provinsi (Perkotaan+Perdesaan)

Ekskresi iodium urin (EIU) anak 6-12 tahun

Nilai nilai statistik EIU pada anak $6-12$ tahun adalah sebagai berikut. Nilai median, rata-rata, mode, standar error rata-rata dan standar deviasi adalah 224; 242; $267 ; 1,57$ dan 143. Nilai rentang, kurtosis dan skweness adalah $985 ; 3,296$ dan 1,477 .
Secara keseluruhan, nilai median EIU pada anak 6-12 tahun $(224 \mu \mathrm{g} / \mathrm{L})$ lebih rendah nilai rata-rata $(242 \mu \mathrm{g} / \mathrm{L})$ atau sebaran miring ke kanan seperti diperlihatkan pada Gambar 2. Oleh karena itu, nilai median lebih cocok untuk digunakan untuk analisis dan bukan nilai ratarata. 


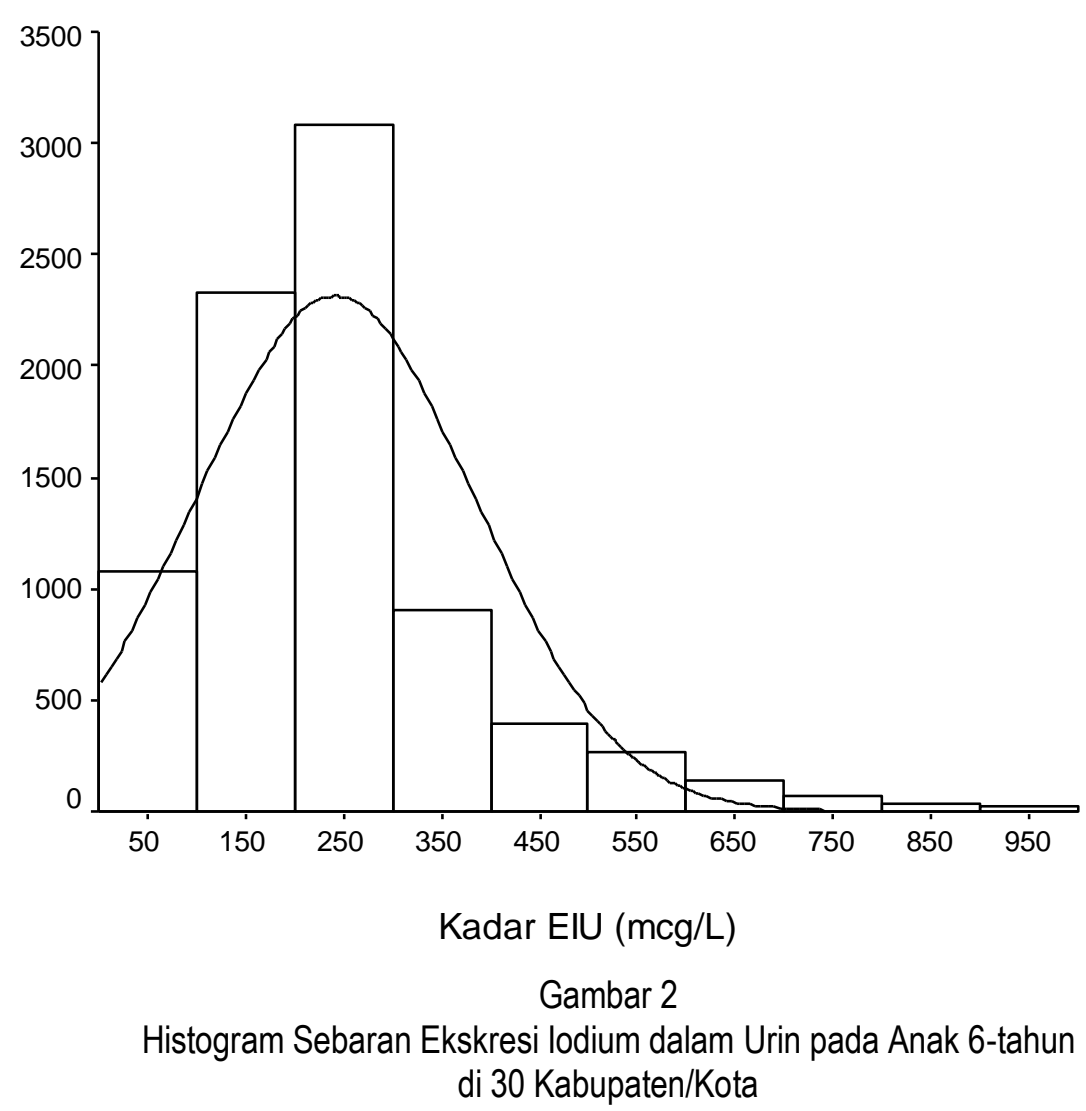

Di 30 kabupaten/kota terpilih, nilai median EIU di Kabupaten Grobogan $(365 \mu \mathrm{g} / \mathrm{L})$ adalah yang tertinggi dan di Kabupaten Klungkung (157 $\mu \mathrm{g} / \mathrm{L}$ ) adalah yang terendah. Ada 2 (dua) kabupaten/kota dengan nilai median EIU diatas $300 \mu \mathrm{g} / \mathrm{L}:$ yaitu Kabupaten Grobogan dan Kota Salatiga. Nilai median EIU di Kota Semarang, Kota Metro dan Kabupaten Katingan telah mendekati $300 \mu \mathrm{g} / \mathrm{L}$ (Table 4). Secara keseluruhan, tidak ada kabupaten/kota dengan nilai median dibawah $100 \mu \mathrm{g} / \mathrm{L}$. Ada 6 (enam) kabupaten/kota dengan nilai median EIU antara 100 - $199 \mu \mathrm{g} / \mathrm{L}$ yaitu Kabupaten Bantul, Kabupaten Bondowoso, Kabupaten Klungkung, Kabupaten Jeneponto, Kota Kendari dan Kota Gorontalo.

Sekitar 4 persen anak mempunyai nilai EIU kurang dari $50 \mu \mathrm{g} / \mathrm{L}$ atau masuk kategori kekurangan iodium tingkat sedang/berat. Sebanyak 9,3 persen anak dengan nilai EIU antara 50 - $99 \mu \mathrm{g} / \mathrm{L}$ atau masuk kategori kekurangan iodium tingkat ringan. Sebanyak 28,0 persen anak mempunyai nilai EIU antara 100 - $199 \mu \mathrm{g} / \mathrm{L}$ atau masuk kategori optimal iodium. Sebanyak 37,1 persen anak dengan nilai EIU antara $200-299 \mu \mathrm{g} / \mathrm{L}$ atau masuk kategori risiko hipertiroidisme akibat iodium dan 21,9 persen anak mempunyai EIU minimal 300 $\mu \mathrm{g} / \mathrm{L}$ atau masuk kategori risiko konsekuensi negatif kesehatan (penyakit tiroid autoimun) (Tabel 5). Secara keseluruhan, persentase anak yang mempunyai EIU kurang $100 \mu \mathrm{g} / \mathrm{L}$ adalah 12,9 persen. Dengan kata lain, persentase anak yang mempunyai nilai EIU diatas $100 \mu \mathrm{g} / \mathrm{L}$ adalah 87.1 persen, jauh diatas 50 persen. 
Tabel 4

Nilai Median dan Rata-Rata Ekskresi lodium Dalam Urin (EIU) Anak 6-12 Tahun di 30 Kabupaten/Kota

\begin{tabular}{|c|c|c|c|}
\hline \multirow[t]{2}{*}{ Kabupaten/Kota (Provinsi) } & \multicolumn{2}{|c|}{ EIU $(\mu \mathrm{g} / \mathrm{L})$} & \multirow{2}{*}{$\mathrm{n}$} \\
\hline & Median & Rata-rata & \\
\hline Tapanuli Tengah (Sumut) & 225 & 226 & 378 \\
\hline Toba Samosir (Sumut) & 230 & 217 & 172 \\
\hline Karo (Sumut) & 221 & 226 & 307 \\
\hline Solok Selatan (Sumbar) & 229 & 227 & 273 \\
\hline Kota Dumai (Riau) & 237 & 220 & 326 \\
\hline Kota Metro (Lampung) & 290 & 319 & 286 \\
\hline Karawang (Jabar) & 229 & 267 & 440 \\
\hline Grobogan (Jateng) & 365 & 425 & 249 \\
\hline Semarang (Jateng) & 244 & 264 & 248 \\
\hline Kota Salatiga (Jateng) & 304 & 336 & 87 \\
\hline Kota Semarang (Jateng) & 288 & 316 & 245 \\
\hline Bantul (DI Yogyakarta) & 192 & 221 & 249 \\
\hline Blitar (Jatim) & 208 & 203 & 305 \\
\hline Jember (Jatim) & 214 & 218 & 428 \\
\hline Bondowoso (Jatim) & 164 & 172 & 197 \\
\hline Nganjuk (Jatim) & 246 & 230 & 347 \\
\hline Kota Pasuruan (Jatim) & 236 & 218 & 318 \\
\hline Kota Tangerang (Banten) & 186 & 223 & 229 \\
\hline Klungkung (Bali) & 157 & 145 & 76 \\
\hline Sikka (NTT) & 209 & 193 & 302 \\
\hline Katingan (Kalteng) & 296 & 332 & 266 \\
\hline Tapin (Kalsel) & 270 & 304 & 130 \\
\hline Balangan (Kalsel) & 257 & 296 & 284 \\
\hline Kota Tarakan (Kaltim) & 219 & 204 & 284 \\
\hline Donggala (Sulteng) & 221 & 265 & 388 \\
\hline Jeneponto (Sulsel) & 181 & 169 & 401 \\
\hline Konawe Selatan (Sultra) & 213 & 237 & 402 \\
\hline Kota Kendari (Sultra) & 187 & 199 & 303 \\
\hline Kota Gorontalo (Gorontalo) & 199 & 214 & 259 \\
\hline Mappi (Papua) & 211 & 240 & 118 \\
\hline 30 Kabupaten/Kota & 224 & 242 & 8297 \\
\hline
\end{tabular}


Tabel 5

Persentase Anak 6-12 Tahun Menurut Nilai Ekskresi lodium Urin (EIU) di 30 Kabupaten/Kota

\begin{tabular}{|c|c|c|c|c|c|c|c|}
\hline \multirow{2}{*}{ Kabupaten/Kota (Provinsi) } & \multicolumn{6}{|c|}{ Persentase Anak Menurut EIU ( $\mu \mathrm{g} / \mathrm{L})$} & \multirow[b]{2}{*}{$\mathrm{n}$} \\
\hline & $<20$ & $20-49$ & $50-99$ & $100-199$ & $200-299$ & $>=300$ & \\
\hline Tapanuli Tengah (Sumut) & 0,8 & 2,6 & 9,0 & 25,7 & 50,8 & 11,1 & 378 \\
\hline Toba Samosir (Sumut) & & & 6,4 & 31,4 & 57,6 & 4,7 & 172 \\
\hline Karo (Sumut) & & 3,6 & 6,5 & 29,3 & 48,5 & 12,1 & 307 \\
\hline Solok Selatan (Sumbar) & & 1,5 & 2,9 & 27,1 & 60,8 & 7,7 & 273 \\
\hline Kota Dumai (Riau) & 0,3 & 1,2 & 5,8 & 26,4 & 61,0 & 5,2 & 326 \\
\hline Kota Metro (Lampung) & & 1,7 & 10,1 & 20,3 & 18,5 & 49,3 & 286 \\
\hline Karawang (Jabar) & 0,2 & 1,1 & 11,4 & 29,1 & 26,6 & 31,6 & 440 \\
\hline Grobogan (Jateng) & & 3,2 & 4,8 & 14,9 & 18,1 & 59,0 & 249 \\
\hline Semarang (Jateng) & 0,8 & 2,0 & 7,7 & 29,4 & 23,8 & 36,3 & 248 \\
\hline Kota Salatiga (Jateng) & & & 5,7 & 18,4 & 25,3 & 50,6 & 87 \\
\hline Kota Semarang (Jateng) & & 2,4 & 7,3 & 15,5 & 26,9 & 47,8 & 245 \\
\hline Bantul (DI Yogyakarta) & & 2,4 & 20,9 & 28,9 & 23,3 & 24,5 & 249 \\
\hline Blitar (Jatim) & 0,3 & 1,3 & 8,9 & 34,8 & 45,2 & 9,5 & 305 \\
\hline Jember (Jatim) & 1,2 & 4,9 & 14,3 & 25,7 & 29,9 & 24,1 & 428 \\
\hline Bondowoso (Jatim) & 1,5 & 5,6 & 15,2 & 41,6 & 24,9 & 11,2 & 197 \\
\hline Nganjuk (Jatim) & 0,3 & 2,9 & 5,8 & 22,5 & 51,6 & 17,0 & 347 \\
\hline Kota Pasuruan (Jatim) & 0,9 & 1,3 & 3,5 & 26,4 & 65,4 & 2,5 & 318 \\
\hline Kota Tangerang (Banten) & & 3,1 & 10,9 & 42,8 & 22,3 & 21,0 & 229 \\
\hline Klungkung (Bali) & 1,3 & 15,8 & 17,1 & 39,5 & 26,3 & & 76 \\
\hline Sikka (NTT) & 1,0 & 5,3 & 9,6 & 30,1 & 53,6 & ,3 & 302 \\
\hline Katingan (Kalteng) & & 1,1 & 2,6 & 12,4 & 36,1 & 47,7 & 266 \\
\hline Tapin (Kalsel) & 0,8 & 2,3 & 10,0 & 24,6 & 21,5 & 40,8 & 130 \\
\hline Balangan (Kalsel) & & 1,8 & 6,3 & 23,6 & 27,5 & 40,8 & 284 \\
\hline Kota Tarakan (Kaltim) & 1,1 & 3,5 & 6,0 & 26,4 & 62,3 &, 7 & 284 \\
\hline Donggala (Sulteng) & & 5,2 & 8,8 & 30,4 & 19,6 & 36,1 & 388 \\
\hline Jeneponto (Sulsel) & 1,7 & 7,7 & 14,0 & 34,2 & 42,4 & & 401 \\
\hline Konawe Selatan (Sultra) & & 3,0 & 10,4 & 31,3 & 28,1 & 27,1 & 402 \\
\hline Kota Kendari (Sultra) & 0,3 & 3,0 & 13,9 & 40,6 & 28,1 & 14,2 & 303 \\
\hline Kota Gorontalo (Gorontalo) & & 5,0 & 15,4 & 29,7 & 28,6 & 21,2 & 259 \\
\hline Mappi (Papua) & & 5,9 & 11,0 & 29,7 & 20,3 & 33,1 & 118 \\
\hline 30 Kabupaten/Kota & 0,4 & 3,2 & 9,3 & 28,1 & 37,1 & 21,9 & 8297 \\
\hline
\end{tabular}

Hubungan antara Ekskresi lodium Urin dan lodium Dalam Garam

Gambar 3 memperlihatkan plot terserak hubungan antara nilai median EIU anak 6-12 tahun dengan persentase rumah tangga yang mengonsumsi garam mengandung cukup iodium hasil tes cepat di 30 kabupaten/kota. Koefisien korelasi Pearson ( $r$ ) antara dua variabel adalah 0,148 dan nilai $p=0,436$. Kabupaten Grobogan merupakan contoh yang unik di mana nilai median EIU tinggi tetapi persentase rumah tangga yang mengonsumsi garam mengandung cukup iodium rendah. Beberapa kabupaten/kota menunjukkan pola hubungan yang kuat antara dua variabel yaitu Kabupaten Tapanuli Tengah, Toba Samosir, Karo, Kota Tarakan dan Kabupaten Mappi dimana persentase rumah tangga yang mengonsumsi garam mengandung cukup iodium tinggi ( $>90 \%$ ) dan nilai median EIU juga tinggi $(>200 \mu \mathrm{g} / \mathrm{L})$. 


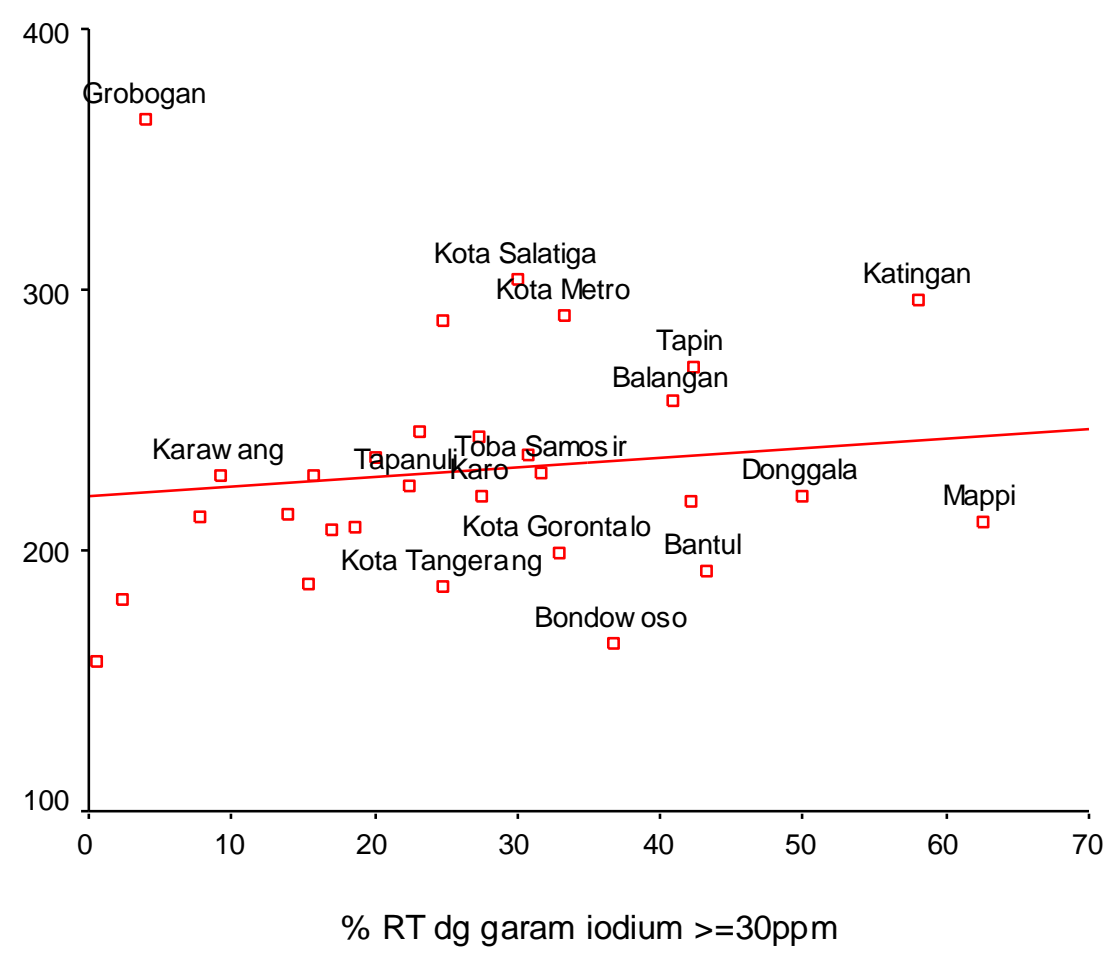

Gambar 3

Plot terserak hubungan antara nilai median EIU anak 6-12 tahun dengan persentase RT yang mengonsumsi garam cukup iodium (tes cepat) in 30 districts/cities

\section{BAHASAN}

\section{Garam beriodium}

Dalam Keputusan Presiden (Keppres) nomor: 69/1994 dinyatakan bahwa garam untuk konsumsi dan industri harus di iodisasi sesuai dengan ketentuan dari Standar Nasional Industri (SNI). Garam untuk konsumsi manusia harus memenuhi SNl: kadar air 7 persen, natrium klorida $>94$ persen, kalium iodat $>30$ $\mathrm{ppm}$, timbal $<10 \mathrm{ppm}$, tembaga $<10 \mathrm{ppm}$, air raksa $<0.1 \mathrm{ppm}$ dan arsen $<0.1 \mathrm{ppm}$. Salah satu alasan mengapa garam beriodium dipilih adalah karena garam dikonsumsi oleh hampir semua lapisan penduduk suatu masyarakat dan oleh semua tingkatan ekonomi. Garam didefinisikan sebagai 'beriodium' jika iodium ditambahkan dalam bentuk apapun: kalium iodida, kalium iodat, kalsium iodida, natrium iodida dan sebagainya ${ }^{8}$. Pada akhirnya, diharapkan bahwa istilah 'beriodium' digunakan jika iodium ditambahkan apapun bentuknya.

Survei Garam Beriodium Nasional telah dilakukan secara teratur hampir setiap tahun sejak 1995 oleh BPS dan Departemen
Kesehatan dengan dukungan dari UNICEF dan Bank Dunia. Survei tersebut diintegrasikan ke dalam SUSENAS. Hasil survei menunjukkan penggunaan garam iodium yang mengandung cukup iodium oleh rumah tangga di Indonesia menunjukkan 50 persen pada tahun 1995, 64 persen pada tahun $2000^{4}$ ), dan 72,8 persen pada tahun 20056). Proyek intensifikasi program penanggulangan GAKI tahun 1998-2003 telah memacu penggunaan garam beriodium oleh rumah tangga dari 62.1 persen pada tahun 1997 menjadi 72.4 persen pada tahun 2003.

Garam Beriodium untuk Semua atau Universal Salt lodization mensyaratkan minimal 90 persen rumah tangga mengonsumsi (menggunakan) garam mengandung cukup iodium. Tabel 1 menunjukkan 86 persen rumah tangga telah menggunakan garam beriodium. Namun, baru 62.3 persen rumah tangga menggunakan garam mengandung cukup iodium. Dari hasil analisis iodium dalam garam dengan cara titrasi masih ditemukan 50 persen garam rumah tangga mengandung kurang dari 20 ppm iodium ${ }^{9}$. Kadar 20-40 ppm iodium dalam garam merupakan batas yang dianjurkan 
agar dapat memberikan $150 \mu \mathrm{g}$ iodium per orang per hari. Demikian, maka diperlukan upaya terpadu (industri, perdagangan dan kesehatan) untuk mempercepat pencapaian garam beriodium untuk semua.

\section{Ekskresi iodium urin (EIU)}

EIU telah diterima sebagai biomarker dari kekurangan iodium karena lebih dari 90 persen iodium dari tubuh dikeluarkan melalui urin sehingga iodium urin mencerminkan konsumsi iodium ${ }^{5}$ dan mengumpulkan sampel urin di lapangan lebih mudah dibandingkan sampel darah. Nilai median ekskresi iodium dalam urin $100 \mu \mathrm{g} / \mathrm{L}$ digunakan sebagai batas untuk menyatakan tidak ada masalah kekurangan iodium dengan minimal 50 persen masyarakat sampel ada di atas $100 \mu \mathrm{g} / \mathrm{L}$. Ditambah lagi, kurang dari 20 persen sampel yang berada di bawah $50 \mu \mathrm{g} / \mathrm{L}$.

Tabel 4 menunjukkan bahwa secara nasional nilai median EIU adalah $224 \mu \mathrm{g} / \mathrm{L}$ atau dalam kategori asupan iodium cukup. Nilai median EIU masih belum memadai di Kabupaten Klungkung dan Bondowoso tetapi sudah cenderung kearah tinggi di Kabupaten Grobogan dan Katingan. EIU anak usia sekolah yang kurang dari $100 \mu \mathrm{g} / \mathrm{L}$ sebesar 13 persen namun yang lebih $300 \mu \mathrm{g} / \mathrm{L}$ atau risiko kelebihan iodium sebesar 22 persen (Tabel 5). Dari Tabel 4 dan Tabel 5 dapat disimpulkan bahwa tingkat fortifikasi $30 \mathrm{ppm} \mathrm{KIO}_{3}$ dalam garam yang saat ini berlaku dapat dikatakan masih cukup aman. Rekomendasi WHO/UNICEF yang terbaru adalah naik untuk ibu hamil dan menyusui yaitu menjadi $250 \mu \mathrm{g} / \mathrm{L}$ per hari ${ }^{10)}$.

\section{Hubungan ekskresi iodium urin dengan iodium dalam garam}

Koefisien korelasi Pearson ( $r$ ) antara dua variabel adalah 0,148 atau sangat lemah tapi hubungan positif antara nilai median EIU dan persentase rumah tangga yang mengonsumsi garam mengandung cukup iodium dengan nilai $p=0,436$. Bagaimanapun, hubungan itu menunjukkan semakin tinggi persentase rumah tangga yang mengonsumsi garam mengandung cukup iodium semakin tinggi nilai median EIU. Contoh yang ekstrim adalah Kabupaten Grobogan di mana nilai median EIU tinggi tapi persentase rumah tangga yang mengonsumsi garam mengandung cukup iodium rendah. Dari grafik ini dapat dikatakan bahwa peran garam beriodium sebagai sumber asupan iodium tidaklah dominan.

\section{SIMPULAN}

1. Sasaran untuk garam beriodium untuk semua yaitu minimal 90 persen rumah tangga menggunakan garam mengandung cukup iodium, masih belum tercapai

2. Asupan iodium pada anak usia sekolah yang didasarkan pada nilai median EIU masih berada di dalam batas sasaran rencana aksi nasional penanggulangan GAKI

\section{UCAPAN TERIMA KASIH}

Ucapan terima kasih kepada DR.Sunarno Ranu Widjojo, MPH sebagai Kepala Pulitbang Gizi dan Makanan atas pengarahan dan kesempatan yang diberikan dalam pengumpulan data ini. Kepada DR. Sandjaja, $\mathrm{MPH}$, terima kasih atas waktu dan bantuan yang diberikan pada awal manajemen data. Terima kasih ditujukan kepada DR.Atmarita, $\mathrm{MPH}$ yang telah membantu dalam perencanaan kegiatan ini. Kepada UNICEF Jakarta yang telah mendukung secara finansial dan khususnya kepada Anna R.Winoto dan DR. Sunawang, MSc yang telah membantu kelancaran proses di UNICEF. Terima kasih disampaikan kepada semua pihak yang telah membantu dalam kegiatan ini yang tidak disebutkan di sini.

\section{RUJUKAN}

1. Hetzel BS. An overview of the prevention and control of iodine deficiency disorders. In: The prevention and control of iodine deficiency disorders. Hetzl BS, JT.Dun and JB.Stanbury (eds.). Amsterdam: Elsevier, 1987.

2. Bleichrodt, N and Born MP. A metaanalysis of research on iodine and its relationship to cognitive development. In: The damaged brain of iodine deficiency. JB.Stanbury (eds.). New York: Cognizant Communication Corporation, 1994.

3. Gautam KC. Global progress in addressing iodine deficiency through universal salt 
iodization: the makings of a global public health success story - the second decde (1995-2007). SCN News 2007, 35:12-18.

4. Badan Pusat Statistik, Departemen Kesehatan dan Bank Dunia. Hasil Survei Konsumsi Garam Yodium Rumah Tangga. Jakarta: BPS, 2000.

5. ICCIDD/UNICEF/WHO. Assessment of lodine Deficiency Disorders and Monitoring their Elimination. A guide for program managers.Third edition. Netherland: UNICEF/WHO, 2007.

6. Tim Penanggulangan GAKY Pusat. Rencana Aksi Nasional Kesinambungan Program Penanggulangan Gangguan Akibat Kurang Yodium. Jakarta: s.n, 2005.

7. Direktorat Gizi Masyarakat dan Direktorat Statistik Kesejahteraan Rakyat. Integrasi
Indikator Gizi Dalam SUSENAS Tahun 2005: Program Perbaikan Gizi Masyarakat Tahun 2005. Laporan Kegiatan.

8. Mannar MGV and Dunn JT. 1995. Salt iodization for the elimination of iodine deficiency. Netherlands: Micronutrient Initiative/ICCIDD/UNICEF/WHO, 1995

9. Survei indikator gangguan akibat kekurangan iodium, Rikesdas. Laporan akhir. Bogor: Pusat Penelitian dan Pengembangan Gizi dan Makanan dan Unicef. 2008.

10. WHO/UNICEF. Reaching optimal iodine nutrition in pregnant and lactating momen and young children. Joint statement by World Health Organization and United Nations Children's Fund. S.l: WHO/UNICEF, 2007. 